\title{
Monitoring of the aquatic environment by species accumulator of pollutants: a review
}

\author{
Oscar RAVERA \\ CNR Istituto Italiano di Idrobiologia, Largo Tonolli 50, 28922 Verbania Pallanza, Italy \\ e-mail: o.ravera@iii.to.cnr.it
}

\begin{abstract}
This paper is a short review on the biomonitoring of aquatic environments by animal and plant species accumulators of toxic pollutants ("scavengers"). This monitoring is based on the relationship between the pollutant concentration in the organism and that in its environment, and not on alterations produced by pollution on the biota. The latter is the basis of other types of biomonitoring, such as those based on the biotic and diversity indices and saprobic scale. The various aspects of monitoring by pollutant accumulators are illustrated; for example, the uptake and loss of pollutants, the "critical organs" and "tissues", the detoxification mechanisms and the most common factors (C.F., BAF, BSAF) for establishing a connection between the pollutant concentration in the organism and that in its environment. Several examples of this monitoring on heavy metals, radioisotopes and organic micropollutants are reported. The advantages of this monitoring, the characteristics of the species to be used as bioaccumulators and some practical suggestions are listed. A close collaboration between the scientific teams working on the biomonitoring based on accumulator organisms and on the chemical monitoring is recommended from the scientific and economic point of view.
\end{abstract}

Key words: uptake and loss kinetics, detoxification, heavy metals, radioisotopes, biocides, hydrocarbons, plankton, aquatic plants, molluscs, fish

\section{INTRODUCTION}

The biological monitorings commonly used are based on the presence or absence of taxa indicators of environmental wellbeing (e.g. biotic indices) or on the complexity of the community identified with the level of environmental wellbeing (e.g. diversity indices).

Biological monitoring (biotic and diversity indices) is not a direct measure of the biological effect produced by pollution, because the observed alterations may be due, in addition to the pollutants, to other stress (e.g. natural or anthropogenic stress not caused by pollutants). Nevertheless, biological monitoring, when applied to the same community over time, may detect some biological modifications, showing that the community, and then the physical environment, has been stressed. As a consequence biological monitoring may be considered a useful "warning signal".

Ascertaining if the nature of the stress is chemical, and identifying and quantifying the pollutants, obviously involves chemical monitoring.

Therefore, it is necessary to combine both biological and chemical monitorings, because one method cannot replace the other (e.g. Flanagan \& Toner 1972; Perret 1977). The advantages and limits of the chemical and biological monitoring methods are discussed in other papers (e.g. Ravera 1998).

There is another type of monitoring based on the capacity which certain taxa ("scavengers") have of accumulating relatively large amounts of several pollutants, without apparent noxious effects. The adoption of this monitoring may be useful to complement both chemical and biological monitorings.

This paper concerns the major aspects of monitoring by accumulator taxa.

\section{UPTAKE AND LOSS OF POLLUTANTS}

When a substance is taken up by an organism, a fraction is metabolised and utilised for its physiological needs (e.g. energy supply, growth, reproduction) or accumulated in some tissues, and a part, which cannot be utilised, is released into the environment. As a result of the metabolism, the compounds taken in are broken down in to simpler substances or built up in to more complex ones. The concentration of a substance in an organism is the result of the difference between the amount of the substance taken in and that released into the environment.

By taking up organic and inorganic substances, aquatic organisms can attain in their bodies concentrations of many substances which are far higher than those in their environment. Consequently, the organism may be considered a concentrator of the greatest part of the substances taken up, and therefore a decelerator of their geochemical cycles. In the body of the organism the concentrations of some elements remain fairly constant (e.g. nitrogen, sodium, potassium), while others may be accumulated in excess of the organism's physiological needs (e.g. phosphorus in phytoplankton, manganese in the bivalve molluscs, gold in Equisetum and maize). 
The concentration of a pollutant in an organism is the result of many variables such as the concentration of the pollutant in the water, the physical-chemical form of the pollutant, the membrane permeabilities of the organism, the type and quantity of food and its degree of contamination, the physiological state of the organism and the characteristics of the physical environment, influencing the organism as well as the pollutant.

Aquatic vegetation (phytoplankton and macrophytes) can take up nutrient and toxic substances from the water and the interstitial water of the sediments only in soluble form.

The substances, and thus also the toxic ones, are taken up by aquatic animals via two pathways: uptake with food and direct uptake from the water. Because the relative importance of each of these pathways is strongly influenced by biological and environmental factors, it is not easy to generalise about the contribution of the different pathways to the pollutant accumulation in the organisms. Indeed, some species uptake pollutants mainly from food, others from the water. For example, fish and other aquatic animals take up methylmercury by direct absorption from the water, through the gill membrane and skin, as well as by the ingestion and successive digestion of contaminated food. The brown bullhead (Ameiurus nebulosus) uptakes mercury from its food but also an important percentage from the water, because of its scaleless permeable skin (Rose et al. 1999). Jernelof (1972) estimated that the pike (Exos lucius) derived $50 \%$ of its methylmercury body burden from food and 50\% from water, whereas whitefish (Coregonus clupeiformis) derived only 10\% from food and $90 \%$ from water. Phillips \& Buhler (1978) demonstrated that rainbow trout (Salmo gairdneri) accumulates $70 \%$ of its mercury from food. According to Janssen \& Scholz (1979), the blue mussel (Mytilus edulis) uptakes only $10 \%$ of its cadmium from its food; a lower percentage $(0.2-0.5 \%)$ was measured by Borchardt (1983) for the same metal in the same species. Harvey \& Luoma (1985) reported that another bivalve (Macoma balthica) takes up about $82 \%$ of cobalt $\left({ }^{57} \mathrm{Co}\right)$ from its food.

Some pollutants (e.g. heavy metals, hydrophobic organic compounds), bound or adsorbed by some forms of organic matter, decrease their power of penetration through the organism's membranes. Among the dissolved forms of the pollutants, the ionic form is the best available (e.g. Zamuda \& Sunda 1982). For example, Kim et al. (1999) found that the toxicity affecting Ceriodaphnia dubia was clearly related to the ionic copper concentration rather than to total copper, because a fraction of copper was complexed by the dissolved organic matter. Sprague (1968) observed that the chelator NTA (nitrilotriacetic acid) reduces copper and zinc uptake by fish. Ravera et al. (1973) found that even relatively low concentrations of chelators (NTA and EDTA) reduce the radiozinc $\left({ }^{65} \mathrm{Zn}\right)$ and radiocobalt $\left({ }^{58} \mathrm{Co}\right)$ up- take by Unio mancus (freshwater Lamellibranch) and Eudiaptomus padanus (freshwater copepod) figure 1. Premazzi et al. (1979) noted that the effect of $\mathrm{Cu}, \mathrm{Cd}$, $\mathrm{Ni}, \mathrm{Hg}, \mathrm{Zn}$ and $\mathrm{Pb}$ on Selenastrum minutum (unicellular green alga) population growth was reduced if the toxic elements were chelated by EDTA or humic acids.
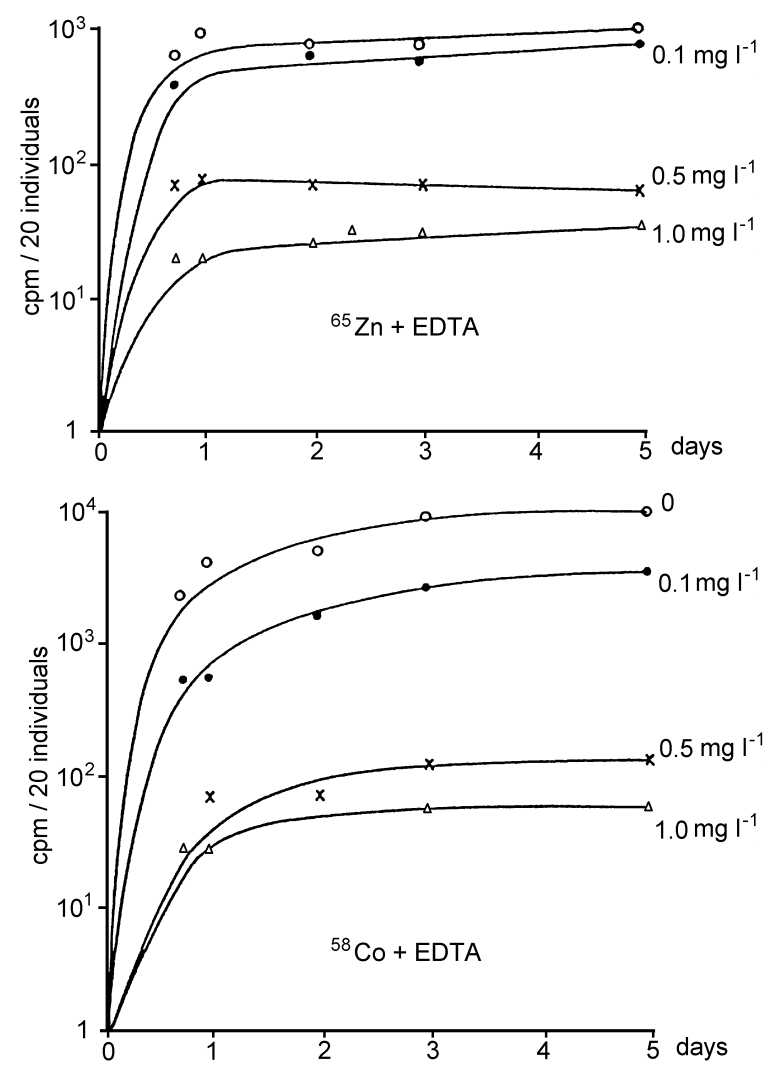

Fig. 1. Effect of different concentrations of EDTA on the uptake of ${ }^{65} \mathrm{Zn}$ and ${ }^{58} \mathrm{Co}$ by a freshwater copepod Eudiaptomus padanus (Ravera et al. 1973).

Absil et al. (1994a; 1994b) carried out accurate experiments to evaluate the percentage of copper incorporated by the bivalve Macoma balthica from its food, consisting of the diatom Phaeodactylum tricornutum labelled with ${ }^{64} \mathrm{Cu}$. Because the biological availability of metal complexed by chelators is very small, EDTA was added to the water to minimise the uptake by the mollusc of dissolved ${ }^{64} \mathrm{Cu}$ leaked from the labelled diatoms. In a control experiment, unlabelled diatoms were fed to the mollusc in the presence of dissolved ${ }^{64} \mathrm{Cu}$, with and without EDTA to assure a similar filtration-rate. The results of the experiments clearly demonstrated that the uptake of copper from the food was at least as important as the uptake from the water.

Information on the influence of the physiological characteristics of the organism on its capacity for accumulating pollutants is not abundant.

From the results of a study on mercury concentration in the muscle of three fish species (Perca flavescens, 
Micropterus salmoides, Ameiurus nebulosus) from 24 lakes of Massachusetts, Rose et al. (1999) attributed the differences between the species to their growth and metabolic rates, without excluding other causes. They found a good positive correlation between the weight of Micropterus and the mercury concentration in its body. The higher concentration in the larger (older) individuals is probably due to the longer time required to accumulate mercury and to the more rapid accumulation-rate than the mercury dilution rate caused by body growth. The slow growth and metabolic rates were due to the age of the oldest fish. Conversely, the other two species, which have a shorter life span than that of Micropterus, have a more rapid growth rate, and consequently an internal dilution of their mercury body burden, thereby offsetting the probable accelerated mercury uptake due to their more rapid metabolism.

The authors who have tried to establish a relationship between the pollutant concentration in the biota and the trophic level of the environment have obtained varying results.

Larsson et al. (1992) measured PCBs and DDE concentrations in pikes (Exos lucius) from 61 Scandinavian lakes. These lakes received a similar pollutant load from diffused sources. In spite of this, wide differences in PCB and DDE concentrations in pikes from different lakes were evident. The concentrations of these pollutants in the fish decreased with the increasing trophic level of the lake and the concentration of humic substances in the water. According to these authors, by knowing the trophic level of a water body and its concentration in humic substances, the pollutant concentration in the fish may be predicted. Rose et al. (1999) measured the mercury concentration in three fish species from 24 lakes (Massachusetts, U.S.A.). No connection between mercury concentration in the fish and the trophic level of the lake was evident. Other authors (e.g. Lindberg et al. 1987; Richman et al. 1988) state that the pollutant concentration in the animal may be influenced by the trophic level of its environment, but other variables may profoundly affect this relationship.

The relationship between the trophic degree of the lake and fish contamination, established by Larsson et al. (1992), is based on two facts. In eutrophic lakes, the concentration of suspended particles (e.g. phytoplankton) is higher, and fish growth is faster than that in lakes poor in nutrients. These causes produce the following effects. Sedimentation of particles which have adsorbed pollutants increases the pollutant content of the sediments and, consequently, the pollutant concentration in the water column decreases. The faster growth of fish enhances pollutant dilution in its body. In addition, in eutrophic lakes humic substances are abundant and chelate several pollutants, which become less available to the organisms.

The study by Larsson et al. (1992) concerned a series of lakes which received a similar pollutant load from diffused sources. The situation is very different in the lakes which receive pollutant loads, quali- and quantitatively different, from point sources. In this case, the relationship between the trophic level of the lake and the pollutant concentration in the organism may not be evident. In general it is very difficult to separate the influence of eutrophication from that of other factors. This may explain the discrepancy between the conclusions of the different authors.

Tab. 1. Total polychlorophenyl concentrations in phytoplankton, zooplankton, zebra mussel and water. The values for the organisms are expressed in $\mathrm{ng} \mathrm{g}^{-1}$ d.w., those for water in $\mathrm{ng}^{-1}$ (by Willman et al. 1999).

\begin{tabular}{lcc}
\hline Date & Sample & Total \\
\hline May 8 & water & 3.03 \\
& phytoplankton & 639.81 \\
& zooplankton & 1669.78 \\
& zebra mussel & 1434.76 \\
June 25 & water & 4.62 \\
& phytoplankton & 331.61 \\
& zooplankton & 678.07 \\
& zebra mussel & 1014.72 \\
August 14 & water & 3.88 \\
& phytoplankton & 115.25 \\
& zooplankton & 667.93 \\
& zebra mussel & 386.57 \\
September 26 & water & 2.87 \\
& phytoplankton & 283.92 \\
& zooplankton & 1143.97 \\
& zebra mussel & 405.63 \\
\hline
\end{tabular}

Transfer of pollutants through food webs may result in an increasing concentration from the producers to the top consumers. This progressive accumulation is called biomagnification. For example, the biomagnification of lyophilic substances (e.g. DDT) from phytoplankton to sea birds is well known. On the other hand, biomagnification does not occur for all pollutants and food chains; for example, Connel \& Sanders (1999) estimated that the cadmium concentration in Eurytemora affinis (marine copepod) is about $50 \%$ of that present in an equivalent biomass of phytoplankton on which Eurytemora fed. Willman et al. (1999), as well as studying the partitioning of polychlorobiphenyls (PCBs) between phytoplankton, zooplankton, zebra mussel (Dreissena polymorpha) and water, looked at the biomagnification of (PCBs) from phytoplankton to zooplankton and from phytoplankton to Dreissena. The biomagnification factor (BMF) was calculated from the ratio of concentrations between the consumers (zooplankton and Dreissena) and their food (phytoplankton). Table 1 shows the PCBs concentration values in water, phytoplankton, zooplankton and zebra mussel; those of the BMF values, calculated on the values listed in table 1 , are listed in table 2. The BMF value of total PCBs for 


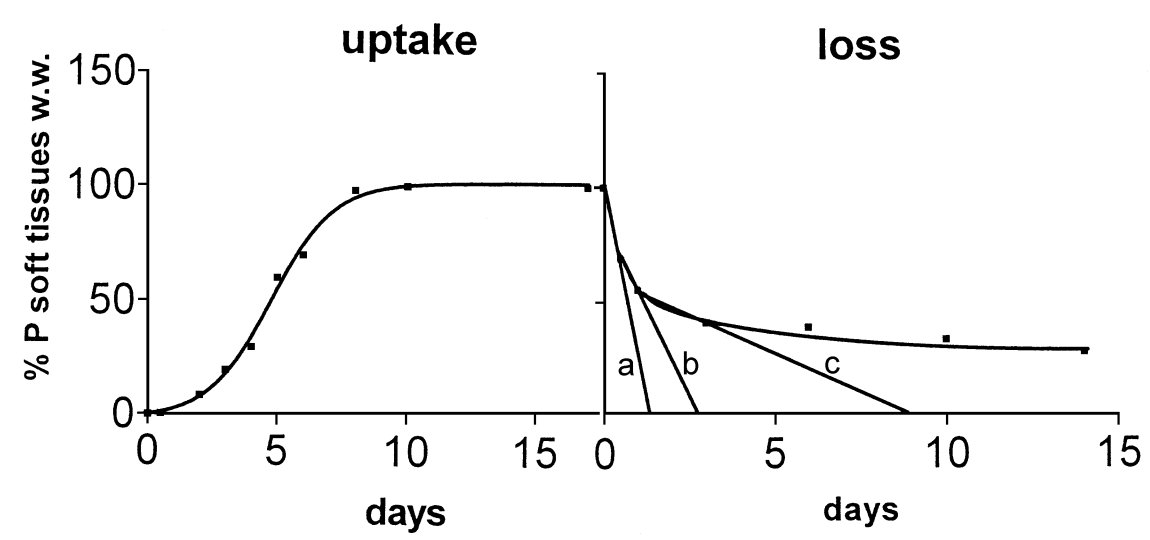

Fig. 2. Uptake and loss of phosphorus by the freshwater gastropod Viviparus ater. The releasing process has been arbitrarily divided into three biochemical compartments corresponding to three compounds with different turnover times: 1) compounds with a short turnover time, indicated by a tangent; 2 ) intermediate with a longer turnover time (b tangent) and 3) very stable with a very long turnover time (Ravera \& Mazzoleni 1965).

zoo/phytoplankton varies with the season from a maximum 5.79 in August to a minimum 2.04 in June and for Dreissena/phytoplankton from a maximum 3.35 in August to a minimum 1.43 in September. The authors do not assume that BMF represents equilibrium conditions.

Tab. 2. Ratios between the total polychlorobiphenyl concentrations in zooplankton and those in phytoplankton and between zebra mussel and phytoplankton (the values were calculated from the data listed in table 1 by Willman et al. 1999).

\begin{tabular}{lcc}
\hline Date & zoo/phyto & mussel/phyto \\
\hline May 8 & 2.61 & 2.24 \\
June 25 & 2.04 & 3.06 \\
August 14 & 5.79 & 3.35 \\
September 26 & 4.03 & 1.43 \\
mean & 3.62 & 2.52 \\
\hline
\end{tabular}

The seasonal variations of the BMF values are the consequence of the variations of both the consumer and its prey. The BMF values are greater for zooplankton/phytoplankton than those calculated for mussel/phytoplankton.

If an environment receives a foreign pollutant, the organism living in it will start to take up the pollutant, from the water or/and food, and concentrate it in its body. Assuming that the pollutant concentration in the environment is constant over time and the organism is maintained in a physiological steady state, the pollutant concentration in the organisms body increases according to a logistic curve. The curve shows the same pattern as those describing population growth in an environment with limited resources, and vertebrate body growth (Fig. 2).

At first, the pollutant concentration in the organism slowly increases in a positive acceleration phase, then rapidly increases, approaching an exponential curve; finally the acceleration declines more and more until the zero-rate is reached. The point of zero-rate corresponds to the equilibrium level between the concentration of the pollutant in the organism and that in the environment. This maximum concentration reached by the organism does not vary over time, at least theoretically, if the conditions of the organism and those of its environment are maintained constant.

Conversely, a continuous decrease of the pollutant concentration in the medium produces a corresponding release of the pollutant from the organism, with some delay. The same effect is obtained by transferring the contaminated organism into a non-polluted environment, or when the organism's mass grows more than the uptake-rate of the pollutant. This latter process is called "biological dilution" (e.g. Oertel 1993). At first, the pollutant release is very rapid and then becomes slower and slower according to a pattern described by a hyperbole with an upward concavity (Fig. 2). This pattern is the result of the different turnover-times of the various biochemical compartments to which the pollutant is bound. Indeed, the pollutant fraction bound to compounds with a short turnover-time is initially released, and only subsequently are the fractions bound to compounds with a longer and longer turnover-time released. This obviously occurs also for essential elements; for example, the phosphorus of the phospholipids has a very short turnover-time if compared with that of the same element in calcium phosphate (e.g. Ravera \& Mazzoleni 1965).

The kinetics of both pollutant uptake and release by the organism has the same pattern for any substance and animal species, whereas the uptake-and loss-rates are dependent on the characteristics of the organism as well as on those of the pollutant and the environmental conditions. In addition, it is interesting to note that the time needed to reach the highest concentration of the pollut- 
Tab. 3. Concentration, content, percentage and specific activity of ${ }^{54} \mathrm{Mn}$ calculated for the different parts of Unio mancus var. elongatulus (Lago Maggiore, Angera, December 1963; Gaglione \& Ravera 1964).

\begin{tabular}{lccccc}
\hline & \multicolumn{2}{c}{$\mathrm{pCi}^{54} \mathrm{Mn} \mathrm{g}^{-1}$} & & $\mathrm{pCi}^{54} \mathrm{Mn}$ \\
& dry weight & dry weight & $\begin{array}{c}{ }^{54} \mathrm{Mn} \text { as } \% \\
\text { of total }\end{array}$ & $\mathrm{pCi}^{54} \mathrm{Mn} \mathrm{mg}^{-1} \mathrm{Mn}^{+}$ \\
\hline total body & 34.9 & 13.3 & 338.0 & 101 & 39 \\
extrapalleal liquid & 137.8 & 0.5 & 4.6 & 1 & - \\
shell & 13.4 & 12.2 & 117.5 & 35 & 40 \\
total soft tissues & 223.4 & 31.3 & 215.9 & 65 & 30 \\
gills & 366.9 & 44.0 & 59.9 & 18 & 23 \\
mantle & 280.1 & 44.0 & 127.1 & 38 & 31 \\
visceral sac & 84.5 & 13.0 & 26.8 & 8 & - \\
foot & 32.9 & 4.0 & 2.1 & 1 & 21 \\
\hline
\end{tabular}

ant in the organism is, generally, very short compared to that needed to release the same pollutant from the organism, when it is transferred to a non-contaminated environment. This may explain, for example, the high concentration of mercury measured in the biota, even several years after mercury discharge declined in a Canadian river system (Armstrong \& Hamilton 1973; Bishop \& Neary 1974; Parks et al. 1984).

\section{CRITICAL ORGANS AND TISSUES}

Several substances are electively concentrated in some particular organs or tissues, which are called "critical organs" and "critical tissues". For example, iodine is concentrated in a very short time and in a relatively large amount in the thyroid, calcium, strontium and radium in the bones of vertebrates, the shell of molluscs and the carapace of crustaceans, manganese in the gills and mantle of marine and freshwater bivalves (Tab. 3). A study carried out to evaluate the metal content of various species of fish in a Norwegian fjord contaminated by the pollutants of a zinc factory showed that the lead concentration in the liver of the fish was 6 times that in the muscle, and cadmium concentration 42 times (Havre et al. 1972).

Most of the organic micropollutants, for example, PAHs (polycyclic aromatic hydrocarbons) and PCBs (polychlorodiphenyls), because of their high hydrophobicity, are accumulated in the fatty tissue. For this reason the content of lipophylic pollutants in the lipids of an organism is generally considered its total body burden (e.g. Willman et al. 1999). Bruner et al. (1994) observed that Dreissena polymorpha concentrated more lipophilic pollutants (PCBs and PAHs) during the prespawning period than in other periods, because during the prespawning period the bivalve has the maximum content of lipids for germ cell production. Lucas et al. (1970) calculated that the median cadmium concentration in the various species of fish from the American Great Lakes was $94 \mu \mathrm{g} \mathrm{kg}^{-1}$ wet weight for the entire fish and $400 \mu \mathrm{g} \mathrm{kg}^{-1}$ for its liver. Havre et al. (1972) found that the cadmium concentration in fish liver ranged from 80 to $2506 \mu \mathrm{g} \mathrm{kg}^{-1}$ ww and from 3 to $32 \mu \mathrm{g}$ $\mathrm{kg}^{-1} \mathrm{ww}$ in the muscle.

Because pollutants are more concentrated in the critical organs and tissues, it is easier to analyse them there than in the whole organism, and this is particularly useful if the pollutant concentration in the total body is rather low. This method is largely used in radioprotection and ecotoxicology, when the organism is large enough to be dissected to isolate the critical organs and tissues. Advanced techniques now make it possible to measure the distribution of some pollutants in the body of the organism even in very small species. For example, Munger et al. (1999) used microradiography to record the cadmium distribution in the body of a planktonic cladoceran (Ceriodaphnia dubia) and identify the critical organ for this metal; this turned out to be the diverticula of the anterior midgut, the region responsible for nutrient absorption. Another advantage of knowing the pollutant distribution in the various organs consists in predicting in which organ the pollutant effects should most probably occur (Munger et al. 1999).

It was known that $\mathrm{Cd}$ and $\mathrm{Pb}$ concentrations in fish were lower than those in the acanthocephales parasites of their intestine (e.g. Paratenuisentis ambiguus, Pomphorhyncus laevis and Acanthocephalus lucii). Sures et al. (1999) carried out a research to ascertain if this also occurred for other elements. The muscle, liver and intestine of perch (Perca fluviatilis) were analysed for 17 elements and their concentrations compared with those measured in the perch parasite Acanthocephalus lucii. The concentrations of all the analysed elements were higher in the parasite than those measured in the fish organs, except Co, which was higher in the liver of the perch (Tab. 4). Because these parasites are very common in several species of fish from many lakes, they may be used as "critical organisms" for pollutant monitoring.

\section{DETOXIFICATION MECHANISMS}

Some toxic substances which cannot be rapidly released, or only partly excreted, may be permanently or temporarily neutralised by various detoxification 
mechanisms. These mechanisms permit some species to live and reproduce in polluted environments where other species cannot survive.

Tab. 4. Selected data from Sures et al. (1999). Ratios between concentration of heavy metals in the parasite and in the organs of the perch (n.d. $=$ not done) .

\begin{tabular}{lcccc}
\hline & $\mathrm{Cd}$ & $\mathrm{Cu}$ & $\mathrm{Ni}$ & $\mathrm{Zn}$ \\
\hline muscle & n.d. & 250 & 4 & 33 \\
liver & 4 & 25 & 3 & 8 \\
intestine & 20 & 50 & 4 & 8 \\
\hline
\end{tabular}

The detoxification effect of the binding of some heavy metals $(\mathrm{Cd}, \mathrm{Zn}, \mathrm{Hg}, \mathrm{Cu})$ to low molecular weight proteins (thioneins) is well known. Metallothioneins and metallothionein-like proteins have been found in mammals, birds, fish, molluscs and algae (Albergoni \& Piccinni 1979, 1983; High et al. 1997). Thioneins have been found at low concentration in animals living in non-contaminated environments, but in animals exposed to high concentrations of heavy metals, the thionein content rapidly increased (Chen et al. 1975).

There is a great deal of information on the capacity of intracellular calcium phosphate granules for sequestering heavy metals. These mineral concretions, found in fish and aquatic invertebrates, are considered the sites for essential and toxic metal accumulation (Hopkin \& Nott 1979; Brown 1982; Naimo 1995). There is evidence that it is not only the species with these granules which are, at least partly, protected against toxic heavy metals, but also the predators feeding upon them. Indeed, a predator feeding on a prey which accumulates metals (e.g. Cadmium) bound to the granules excretes the granules without metabolising them (Nott \& Nicolaidu 1994). Conversely, bivalves (e.g. Oyster, Mytilus and other molluscs), which can with no apparent in-effects accumulate huge amounts of heavy metals in their tissues, in addition to those in the granules, may damage their more sensitive predators, such as humans. The use of x-ray microanalysis to measure the metal content of the granules in the mussel mantle has been proposed by Adams and Shorey (1998) to monitor contaminated environments.

Crustaceans, and particularly Malacostraca, which have a relatively long life-span, accumulate some pollutants in their exoskeleton. Moulting releases the pollutant accumulated in the exoskeleton; as a result, crustaceans are periodically detoxificated by moulting, which occurs several times during their life-span (e.g. Zatta 1985).

Some algal species protect themselves by trapping and accumulating pollutants (e.g. metals) in their polysaccaridic wall.

Several lypophylic pollutants (e.g. hydrocarbons, organochlorines, organophosphorus compounds) are stored in fat tissues. As a consequence, the fat reserve, when it is not utilised, protects the organism from these pollutants; but when the fat is lipolyzed, the pollutants concentrated in it are distributed in the body of the organism producing damage in relation to their amount and the weight of the organism. Because the concentration of the lyophilic pollutants is usually related to the unit of lipid tissue, rather than to the weight unit of the whole organism, results on the pollutant content may be obtained independently for the percentage of fat present in the various species and from its variations in time. For example, before the reproduction period several fish and mussel species accumulate a great amount of lipids which, during reproduction, is partly utilised as an energy source, but most of which is eliminated by being stored in the germ cells: eggs and spermatozoa. The elimination of lipids with their pollutant content by egg production has also been observed in benthic copepods (Latufo 1998). Lobel \& Wright (1982) measured a very high concentration of zinc in Mytilus edulis eggs and Ravera (1964) a huge amount of strontium in the embryo shells of a freshwater Gastropod (Viviparus ater).

\section{ACCUMULATOR ORGANISMS}

Macroalgae, phanerogames, mosses and periphyton, which have a large free surface compared to their weight, very rapidly concentrate great quantities of various pollutants and are consequently useful indicators of local pollution levels (e.g. Ravera 1966; Neal et al. 1967; Havre et al. 1972; Abo-Rady 1980; Vymazal 1984; Cenci et al. 1993). For example, Cladophora glomerata (L.) Kütz., a sessil Chlorophyta widely diffused in lakes and running waters, was used by some authors as an indicator of pollutants, particularly heavy metals (e.g. Whitton et al. 1989; Oertel 1991, 1993). Although Cladophora has a lower capacity for accumulating heavy metals than aquatic mosses, it was considered by Whitton et al. (1989) one of the best indicators of pollutants in river water. Oertel (1991, 1993) analysed 15 heavy metals and macroelements in Cladophora glomerata during the whole vegetation period, from Hungarian segment of the River Danube. This author observed an evident biological "dilution effect" of the pollutants during the period of the maximum growth-rate of the algal biomass. Subsequently, the growth-rate decreased until a biomass constant over time was reached; during this period the pollutants in the water did not vary either. Oertel (1993) concludes that Cladophora is a useful indicator of heavy metal pollution, if it is analysed after the maximum growth rate and if during this period there are no important pollution episodes (Fig. 3). Ravera (1966) measured the most important gamma-radionuclides from fall-out (Ce144, Ru-106, Cs-137, Zn-95 and Mn-54) in 14 species of macrophytes from five lakes of Northern Italy. The radionuclide concentrations in lake water showed seasonal variations, whereas in aquatic plants a continuous increase of the radionuclide concentrations from 1961 to 


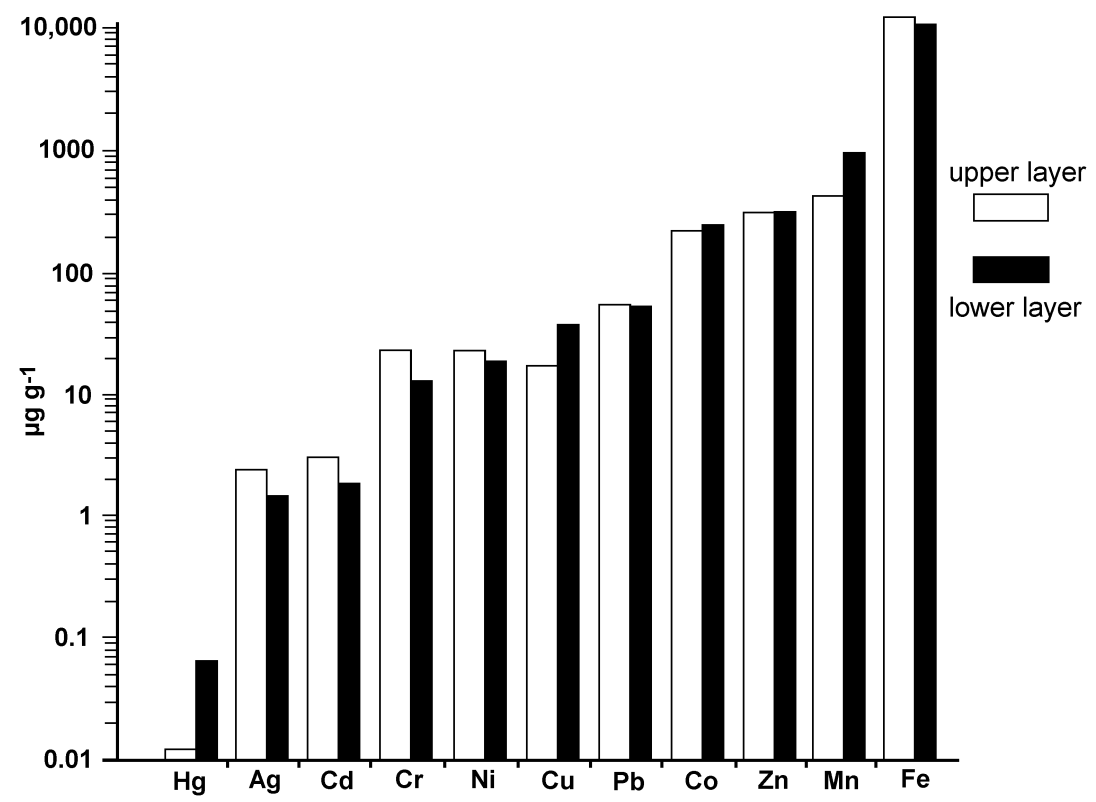

Fig. 3. Mean concentrations ( $\mu \mathrm{g} \mathrm{g}^{-1}$ d.w.) of heavy metals in Cladophora glomerata (L.) Kütz in "supratidal" (upper layer) and "permanent in water" (lower layer) in the Hungarian segment of the River Danube (Oertel 1993).

1962 was observed. In addition, on the basis of the biomass, the radionuclides concentrations in the periphyton were three-four times higher than those in the plant supporting it. This is probably due to the larger free surface of the periphyton than that of the macrophyte per unit of weight.

Other useful indicators of local pollution are zoobenthos species. The benthic detritivorous species may be used as scavengers, after being depurated for an adequate time to release the contaminated sediment present in their gut (Song \& Breslin 1998). Freshwater and marine amphipods are useful as indicators for several heavy metals in the sediments (e.g. Rainbow et al. 1989; Bascombe et al. 1990; Borgmann \& Norwood 1955; Plénet 1995; Song \& Breslin 1998; Twiss \& Campbell 1998).

According to Reichenbach-Klinke (1971) the mercury concentration in the pike may be 3000 times greater than that in the water in which it lives and DDT concentration in the perch 2000 times. Migratory fish, especially those that seasonally migrate from one environment to another (e.g. from a lagoon, an estuary or a fjord to the open sea and vice versa), obviously cannot be good indicators for local conditions (Havre et al. 1972). Conversely, fish species with a limited wandering behaviour may be used as indicators.

Bivalve molluscs are effective accumulators of metals and organic micropollutants, because they filtrate a great volume of water with soluble and particulate substances, which, after being metabolised, are selectively concentrated in their soft tissues or in the shell. In addition, they are generally very resistant to several pollut- ants (e.g. organochlorines) which are dangerous for other animals living in the same environment (e.g. crustaceans, insects). Moreover, these molluscs are sedentary at the adult stage, and several marine and freshwater species are so abundant that frequent sampling has no appreciable effect on their population size. Many species are widespread and are very abundant in any season. In conclusion, bivalves are very useful as "sentinels" to evaluate the importance and spatial distribution of many pollutants. For example, Dreissena polymorpha is a mollusc commonly used to monitor freshwater ecosystems (e.g. Doherty et al. 1993; Sures et al. 1999). The advantage of this bivalve is its wide distribution in the European countries and Northern America.

Czarnezki (1987) used the bivalve Lampsilis ventricosa to monitor heavy metal pollution in running waters. Oertel (1998) measured the heavy metal concentrations in the gills of two bivalves (Anodonta cygnea, Unio pictorum) and in the total soft tissues of a bivalve (Dreissena polymorpha) and three gastropod species (Lymnaea stagnalis, L. auricolaria, Planorbarius corneus) to estimate the impact on a side-arm system of the River Danube by engineering works.

In the framework of the "Mussel Watch Programme" run by the NOAA (National Oceanic and Atmospheric Administration), the USA coastal zones and estuaries were monitored by analysing the pollutants accumulating in the soft tissues of mussels. The data on several pollutants (trace metals DDT, PCB, hydrocarbons and artificial radionuclides) referring to the period 19761978 and reported by Ferrington et al. (1983) were very informative. Because the results from this programme 


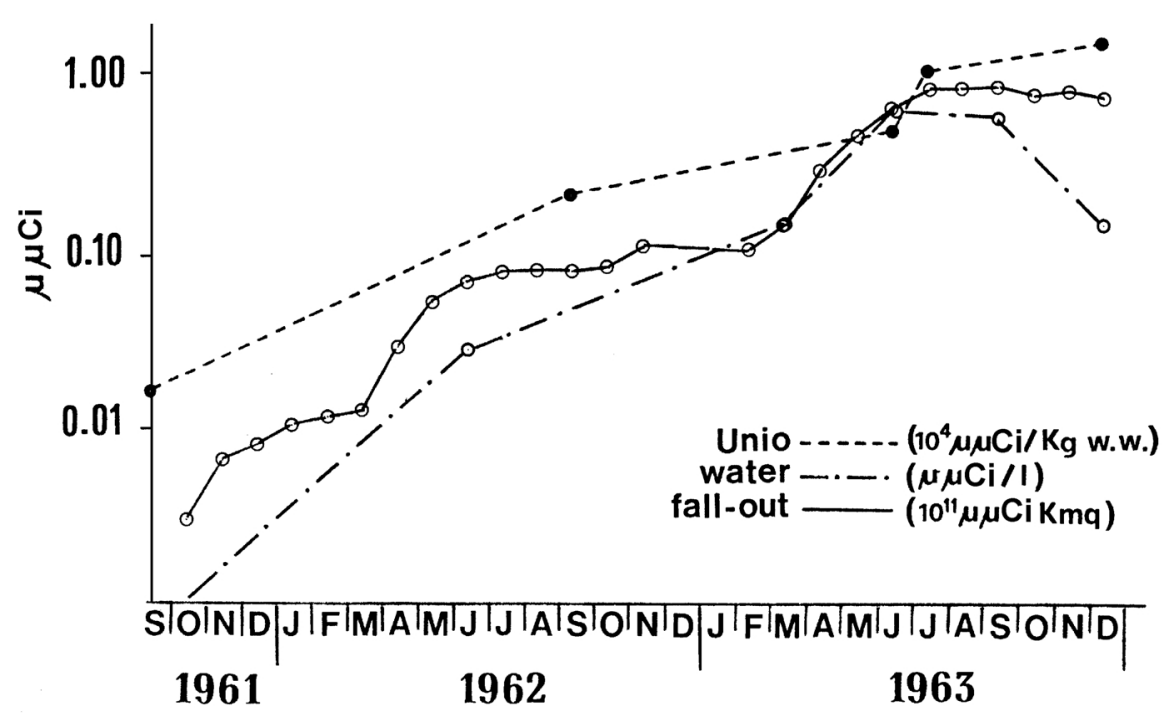

Fig. 4. Concentration of ${ }^{54} \mathrm{Mn}$ in fall-out, lake water and soft tissues of Unio mancus. The values of the fall-out, corrected for radioactive decay, are cumulative (Gaglione \& Ravera 1964).

were satisfying, the "International Mussel Watch" was started in 1992 (O'Connor et al. 1994).

The capacity of the Unionidae (Lamellibranchia) to accumulate manganese in their soft tissues ha been known for more than 90 years (Bradley 1907a, 1907b). In September 1960, for the first time in Europe, radiomanganese $\left({ }^{54} \mathrm{Mn}\right)$ was detected in Unio mancus var. elongatulus (Pfeiffer), a common species of Unionidae collected from Lake Maggiore (Ravera \& Vido 1961). Since this radioisotope was not a local pollutant before 1960 , it was probably present in the fall-out over Northern Italy in undetectable activities in the compartments usually analysed, that is in fall-out, lake water, sediments, aquatic plants, gastropods and fish species. Because of the ability of the Unionidae to accumulate manganese, it seemed interesting to use Unio mancus as a biodetector of ${ }^{54} \mathrm{Mn}$ contamination, especially when the level of this radioisotope was so low as to be not measurable otherwise (Fig. 4). To check this, ${ }^{54} \mathrm{Mn}$ was measured in Unio, in fall-out and in lake water from 1960 to 1963 when the activity of this gamma-emitter in the fall-out increased (Gaglione \& Ravera 1964).

Gastropods (Prosobranchia) are generally less effective accumulators of trace metals than Lamellibranchs. One of the reasons may be their different feeding behaviour: Prosobranchia principally feed on the surface sediment particles, whereas Lamellibranchia are filter feeders. Gommes \& Muntau (1976) measured higher concentrations of Cadmium in the soft tissues of Unio mancus $\left(17.7 \mathrm{mg} \mathrm{kg}^{-1}\right)$ than in those of the Prosobranchia Viviparus ater $\left(0.75 \mathrm{mg} \mathrm{kg}^{-1}\right)$ collected from the same area of Lago Maggiore. In the same environment Ravera (1965) measured extremely low concentrations of stable and radioactive manganese in Viviparus and high concentrations of both these isotopes in Lamellibranchs U. mancus and Anodonta cygnea (Fig. 5). In addition, Viviparus released with its excrement most of the radioruthenium from fall-out taken up (Ravera 1964).

To mimic the uptake and accumulation of lipophilic pollutants (e.g. organochlorine pesticides, PCBs, hydrocarbons) by aquatic organisms, semipermeable membrane devices (SPMDs) have been used (e.g. Huckins et al. 1990; Ellis et al. 1995; Hofelt \& Shea, 1997; Axelman et al. 1999).

The main advantage of this method is that the same device is used in different environments, which concentrates exclusively the liophilic pollutants soluble in the adopted solvent. As a consequence, the concentration of the pollutant in the solvent reflects the concentration of the soluble forms of the pollutant in the environment. Therefore, the results obtained from different environments may be easily compared. Conversely, the uptake and the accumulation of the same pollutants by the organisms depend on several variables (e.g. temperature, peculiar characteristics of the populations, from different areas, physiological state and concentration and type of food). On the other hand, the SPMD technique does not take account of the fact that the organism takes up by sorption and food the various physical forms of the pollutant and not only the soluble one. In conclusion, the SPMD method cannot produce useful results for evaluating the contamination level of the organism; this information is particularly important if the organism is used in the human diet. In addition, by this method only the soluble form of the pollutants present in the water 

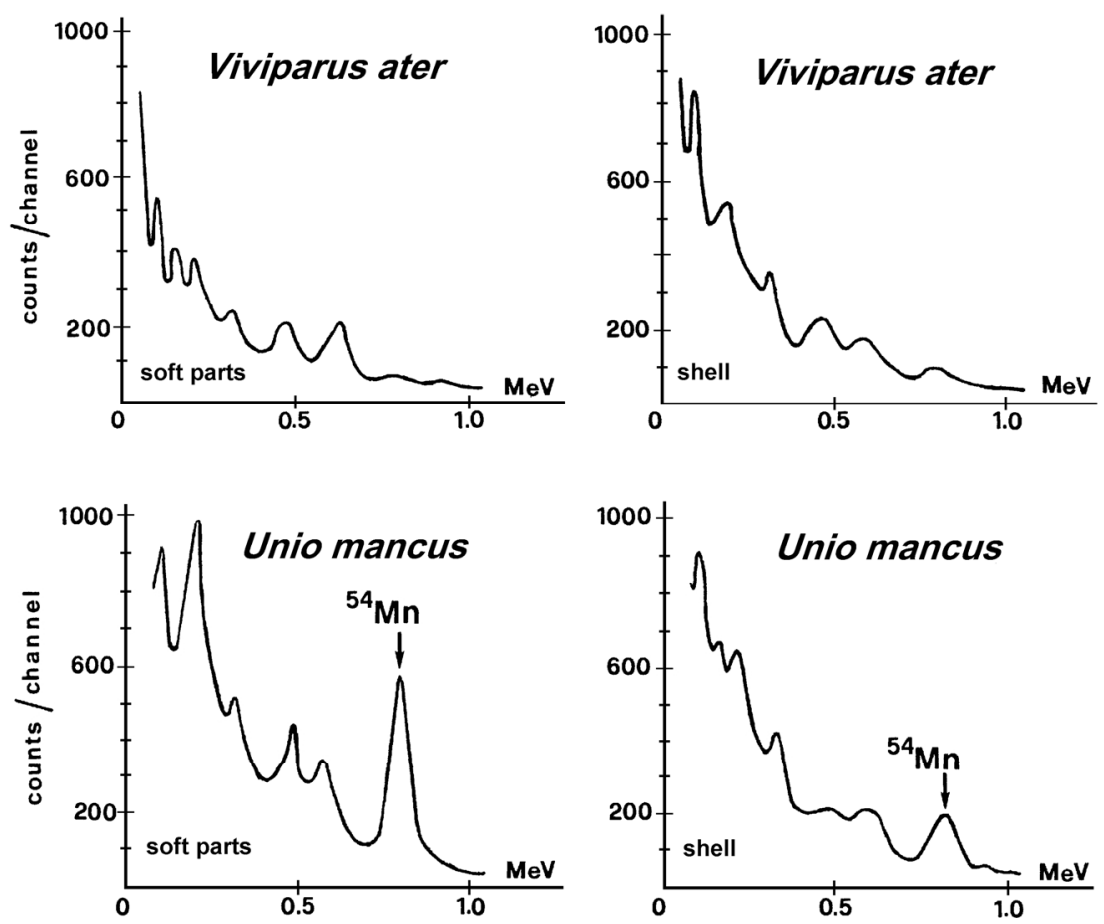

Fig. 5. Gamma spectra of the shell and soft tissues of Viviparus ater (gastropod) and Unio mancus (bivalve) from Lago Maggiore (Northern Italy). The high concentration of ${ }^{54} \mathrm{Mn}$ from fall-out in the soft tissues of Unio is evident (Ravera 1965).

may be measured. Indeed, Axelman et al. (1999) recommended prudence in the use of the SPMD method. The study by these authors also deals with the accumulation of polycyclic aromatic hydrocarbons (PAHs) in SPMD and blue mussels. The results reported in their paper highlight the greater accumulation of PAHs in the mussels than that in the SPMD. For example, in the reference site the mean concentrations $\left(\mathrm{ng} \mathrm{g}^{-1}\right)$ in the SPMD were $1.8 \times 10^{3}$, and $9.6 \times 10^{2}$, and those in the mussels $4.5 \times 10^{3}$ and $2.1 \times 10^{3}$; in a contaminated site the concentrations in SPMD were $8.9 \times 10^{5}$ and $8.3 \times 10^{5}$ and in the mussels $3.0 \times 10^{6}$ and $6.1 \times 10^{6}$.

The large free surface of the plankton organisms (phyto and zooplankton), if related to mass unit, and their active metabolism combine to favour the rapid sorption of various pollutants. Crustacean zooplankters are not able to accumulate chlorinated pesticides because they are very sensitive to these pollutants, as are all the arthropodes.

On the mass unit the concentration of pollutants in the plankton is far greater than that in the water in which it lives. Because of the small plankton biomass in a volume unit of water, the total pollutant content in the plankton is very small if compared with the pollutant content in the same water volume. On the other hand, in the gut content of planktivorous fishes the amount of zooplankton is equivalent to that living in several cubic meters of water.
Lowman (1958) detected radiomanganese $\left({ }^{54} \mathrm{Mn}\right)$ from fall-out in plankton samples from the Marshall Islands, in an area near to the zero point of a nuclear explosion. Acantharia (planktonic protozoa), which have a celestine $\left(\mathrm{SrSO}_{4}\right)$ shell, have been used by Schreiber (1967) to monitor fall-out radiostrontium $\left({ }^{90} \mathrm{Sr}\right)$ in the Adriatic and Tyrrenian Seas.

Filter-feeding zooplankton accumulate in their body several metals, radioisotopes and other pollutants associated to bacteria, algae and suspended organic particles used as food, in addition to the pollutants dissolved in the water. Zooplankton, and particularly freshwater species, which are more abundant than marine ones, may be easily collected by net or pump in a quantity adequate for chemical analyses.

Abundant information exists on pollutant accumulation by phytoplankton; for example, Rice \& Sikka (1973) calculated that dieldrin and DDT are accumulated by marine diatoms, dinoflagellates, chrisophytes and euglenoides to many times the concentrations of both pesticides measured in the water. Unfortunately, it is not easy to collect an amount of phytoplankton sufficient for chemical analyses, except during algal bloom periods.

Studies were carried out with radiotracers to evaluate the partitioning of trace metals from the water into the plankton size fractions (e.g. Ravera 1971; Twiss \& Campbell 1998). Ravera (1971) carried out experiments to evaluate the strontium and cesium concentrations in 
Tab. 5. Concentration factor for ${ }^{85} \mathrm{Sr}$ and ${ }^{134} \mathrm{Cs}$ and percent composition of the 5 planktonic fractions, expressed in biomass. $\mathrm{Ch}=$ Chaoborus; $\mathrm{Cl}=$ Cladocera; $\mathrm{Co}=$ Copepoda; $\mathrm{R}=$ Rotifera; $\mathrm{P}=$ Phytoplankton (Ravera 1971).

\begin{tabular}{|c|c|c|c|c|c|c|c|c|}
\hline \multirow[t]{2}{*}{ Fraction } & \multicolumn{2}{|c|}{ C.F. } & \multirow{2}{*}{$\frac{\text { C.F. }}{{ }^{85} \mathrm{Sr}}$} & \multicolumn{5}{|c|}{$\%$} \\
\hline & ${ }^{85} \mathrm{Sr}$ & ${ }^{134} \mathrm{Cs}$ & & $\mathrm{Ch}$ & $\mathrm{Cl}$ & $\mathrm{Co}$ & $\mathrm{R}$ & $\mathrm{P}$ \\
\hline 1 & 102.0 & 27.1 & 3.76 & 5 & 95 & & & \\
\hline 2 & 21.1 & 12.9 & 1.64 & 5 & 90 & 5 & & \\
\hline 3 & 8.6 & 20.0 & 0.43 & & 30 & 70 & & \\
\hline 4 & 8.9 & 24.3 & 0.37 & & & 98 & 1 & 1 \\
\hline 5 & 14.3 & 87.1 & 0.16 & & & & & 100 \\
\hline
\end{tabular}

five size fractions $(1 \mu \mathrm{m}$ to $950 \mu \mathrm{m})$ of bioseston from Lake Monate (Lombardy, Northern Italy). The differences between $\mathrm{Sr}$ and $\mathrm{Cs}$ concentrations for the different size fractions, tested by ANOVA, showed that both the coarsest fraction $(700 \mu \mathrm{m}$ to $950 \mu \mathrm{m})$ and the finest one ( $1 \mu \mathrm{m}$ to $88 \mu \mathrm{m}$ ) were highly significant from the other fractions. The highest $\mathrm{Sr}$ concentration in the coarsest fraction was probably due to the high percentage (95\%) of Cladoceran biomass (Daphnia hyalina and Leptodora kindtii), which was very rich in calcium, a vicarious element of $\mathrm{Sr}$, and the highest Cs concentration in the finest fraction was probably due to the $100 \%$ of phytoplankton, rich in potassium, vicarious of Cs.

From a comparison of the ratios of the two concentration factors $\left({ }^{85} \mathrm{Sr}\right.$ and $\left.{ }^{134} \mathrm{Cs}\right)$ it is evident that the plankters are able to discriminate between the two radionuclides. In addition, because the concentration factors, for ${ }^{85} \mathrm{Sr}$ as well as for ${ }^{134} \mathrm{Cs}$, are not correlated with particle size, we may suppose that most of the radioisotopes measured in our samples are metabolised by plankters, i.e. that absorption predominates over adsorption (Tab. 5).

Twiss \& Campbell (1998) carried out trace metal scavenging experiments in Lake Erie to evaluate the removal of $\mathrm{Cs}, \mathrm{Cd}, \mathrm{Zn}$ and the rare earth element Gadolinium by picoplankton $(0.2$ to $2 \mu \mathrm{m})$, nanoplankton (2 to $20 \mu \mathrm{m})$ and microplankton $(20$ to $210 \mu \mathrm{m})$. The most important results were the following: a) picoplankton and nanoplankton were most effective scavenging fractions; b) except for picoplankton, Zn was the element most readily scavenged by nanoplankton and microplankton and c) Cs was weakly accumulated by the plankton.

These results highlight the advantage of dividing the plankters into several size classes; indeed, the plankton sample is heterogeneous, being an association of several species, of different size and different capacity for accumulating pollutants. Since the absolute and relative abundance of each species varies with the season, the content of a pollutant in the plankton varies in relation to the season; in addition to the variations emerging from the contamination of both the algae, used by zooplankton as a food, and the water. More homogeneous sub-samples may be obtained by dividing the plankters of the whole sample into a sequence of size classes and analysing the pollutants in these sub-samples.

Pollutant concentrations in scavengers with a long life-span, such as several molluscs and fish, are integrated over time, that is, the present pollutant concentration in the organism is the result of the present and past pollution of the environment. As a consequence, to follow the pollutant variations in an environment over a long period of time (e.g. some years), pollutant contents in the organisms, collected in successive periods of time, must be analysed. This technique has been successfully applied by Tassi-Pelati (1969) to estimate the variations from 1962 to 1967 of fall-out radiostrontium $\left({ }^{90} \mathrm{Sr}\right)$ using as a critical organ the shell of the marine clam Tellina pusilla (Fig. 6). If this sampling plan cannot be adopted, the variations over time of the pollution level may be roughly evaluated by comparing the pollutant concentration in individuals of various ages.

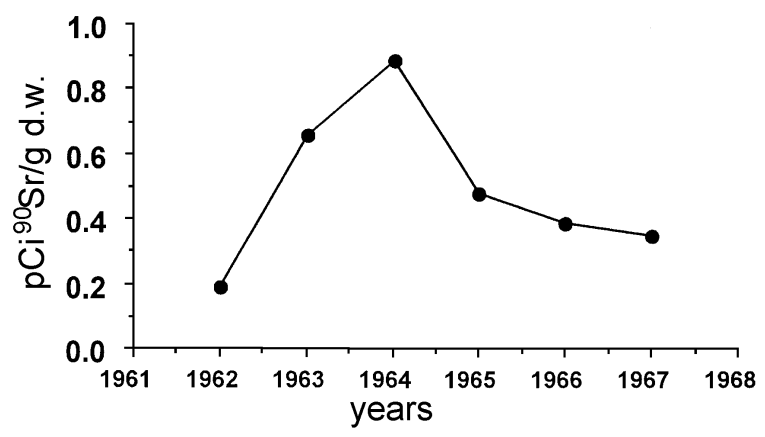

Fig. 6. Variations over time of ${ }^{90} \mathrm{Sr}$ activity from fall-out in the shells of the bivalve Tellina pusilla from the Adriatic Sea (Tassi-Pelati 1969).

To estimate the present pollution level of the environment and its daily variations, short life-span organisms may be used as accumulators. Planktonic organisms are suitable for this purpose, because of their short life-span, their presence in any season in marine and freshwater ecosystems and their great capacity to accumulate several pollutants (e.g. Iorgulescu et al. 1965; Hannerz 1966). An example of this may be the results of the measurements of the fall-out radioactivity $\left({ }^{131} \mathrm{I}\right.$, ${ }^{134} \mathrm{Cs},{ }^{137} \mathrm{Cs}$ and ${ }^{106} \mathrm{Ru}$ ) from Chernobyl in net-plankton 
from two Northern Italian lakes: Lake Monate and Lake Comabbio (Ravera \& Giannoni 1995). These results are illustrated in figure 7.

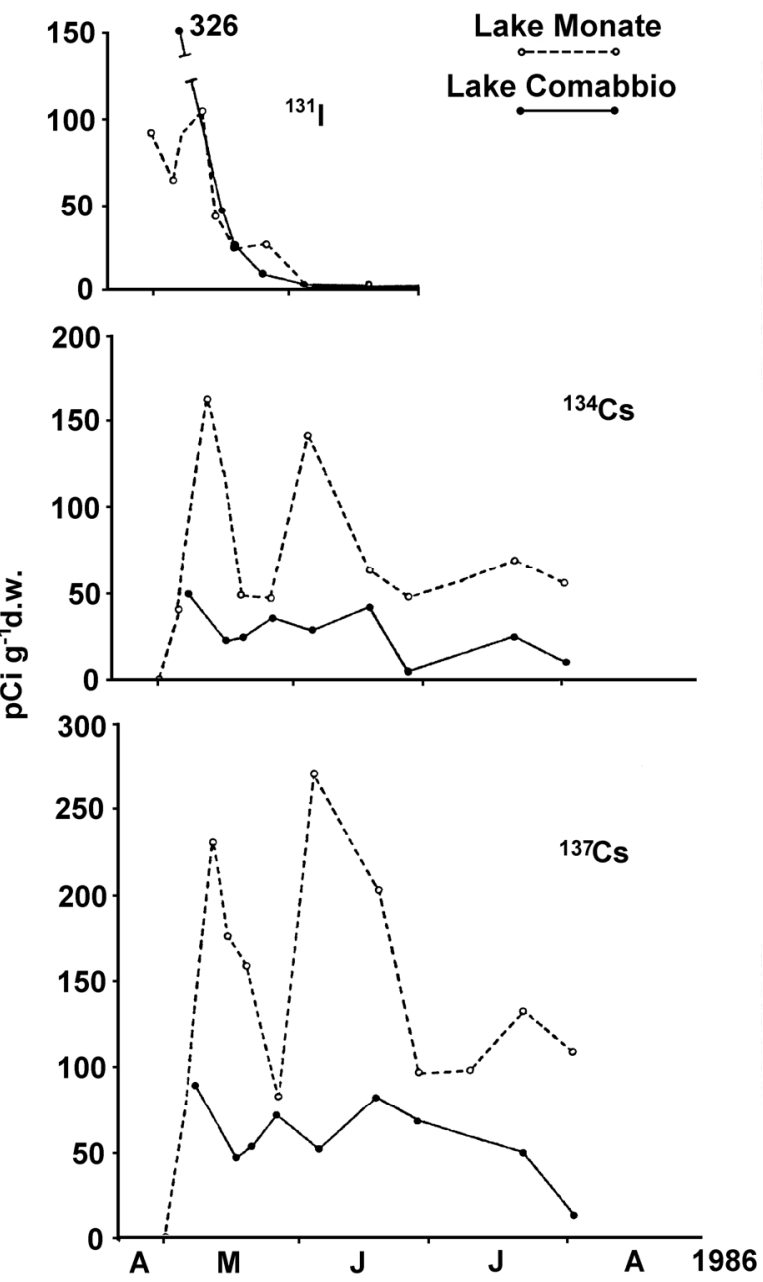

Fig. 7. Pattern over time of radioisotopes $\left({ }^{134} \mathrm{Cs},{ }^{137} \mathrm{Cs},{ }^{131} \mathrm{I}\right)$ from Chernobyl fall-out in net plankton from two Northern Italian lakes: Lake Monate and Lake Comabbio (Ravera \& Giannoni 1995).

In addition to the analysis of specimens living in their environment, there is another technique called "active monitoring". This method consists in transferring organisms, kept in suitable cages, from a non-contaminated environment into a contaminated one. By analysing samples of these organisms collected at successive times the uptake-rate of the pollutants may be calculated. To minimise the stress due to the change of environment, the organisms transferred should belong to the same species as those living in the environment to be monitored, and the new environment should be not too different from the native one. An example of this method is given by the experiment carried out by Parks et al. (1984). An adequate number of individuals of crayfish (Orconectes virilis) were suspended in cages in a contaminated river. The results from this experiment produced important information on mercury contamination of the water course. Crassostrea gigas and Ostrea edulis collected from a clean environment and transferred for a period of 5 months to polluted water con-

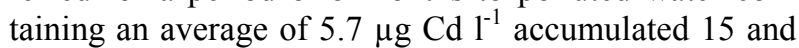
17 times respectively the concentrations of $\mathrm{Cd}$ in control samples (Boyden 1977).

\section{RELATIONSHIP BETWEEN THE POLLUTANT CONCENTRATION IN THE ORGANISM AND THAT IN ITS ENVIRONMENT}

The comparison between the contamination of an aquatic organism in relation to that of the water in which it lives is commonly quantified by the ratio between the concentration of the pollutant in the organism (related to the wet weight) and that in the water. The value of this ratio is called concentration factor (C.F.) for a given pollutant and a given species. The concentration factor may be calculated when in an organism the concentration of a certain pollutant is (or is not) at equilibrium level with that in the water; the first is called "real C.F." or "C.F. at equilibrium", the latter is the "observed C.F." (De Bortoli et al. 1968). When the C.F. value is at equilibrium, the releasing rate of the pollutant from the organism is equivalent to the intaking rate and, consequently, the pollutant concentration in the organism is fairly constant. This may occur if the pollutant concentration in the water is constant over time and the organism is in a physiological steady state.

The C.F. value of each organ or tissue of an organism, obviously, increases with its pollutant concentration. For example, Templeton (1959) calculated the C.F. for ${ }^{90} \mathrm{Sr}$ from fall-out in various organs of a freshwater fish (Leuciscus erythrophtalmus); the values varied from 0.5 for the heart to 209 for the scales. Because the weight of the various organs varies widely, the C.F. of the whole organism is given by the weighted mean of the C.F. of the organs composing its body.

Since the early 1950's the C.F. has been widely adopted in radioprotection studies to predict the amount of radioisotopes concentrated in aquatic species, by knowing the C.F. value of the species for a given radioisotope and the concentration of the same radioisotope in the water. This information is obviously important, particularly for the species used as human food. In addition, this information makes it possible to establish the maximum radioactive load into an aquatic ecosystem which can guarantee an acceptable contamination of the organisms living in it (Recht 1969). Subsequently the C.F. has also been used for non-radioactive contaminants, such as heavy metals and organic micropollutants.

Willman et al. (1999) used the "Biological accumulator factor" (BAF), i.e. the ratio between the pollutant concentration in the organism and that in the water, to calculate the accumulation of polychlorobiphenyls (PCBs) in phytoplankton, zooplankton and zebra mussel 
(Dreissena polymorpha) in relation to $\mathrm{PCB}$ concentration in the water. Because the authors believe that the BAF values may not represent equilibrium conditions, this factor has the same meaning as the "observed concentration factors". The PCB concentration values in phytoplankton, zooplankton and Dreissena and those in the water are reported in table 1. Zooplankton has the highest mean concentration (1040 $\mathrm{ng} \mathrm{g}^{-1} \mathrm{dw}$ ), followed by zebra mussel (810 ng) and phytoplankton (343 ng). Phytoplankton shows the widest seasonal variations, followed by zebra mussel and zooplankton. Because the seasonal variations of PCB concentration in the water are relatively small, if compared with those of the biota, the seasonal variations of the pollutant concentration in phyto-, zooplankton and mussel may be attributed only in part to the PCB variations in the water. The seasonal variation of the $\mathrm{PCB}$ concentration in zooplankton is probably the combined result of the concentration in the phytoplankton as well as the phyto- and zooplankton species successions. The variations of concentration in zebra mussel are due to the combined effect of both temperature and algal food, which varies with the season, but especially to the lipid content, which is controlled by its reproductive cycle.

Because the sediment seems to be the most important source of pollutants for benthic species, the pollutant concentration in the organism is compared with that in the sediment, instead of with the concentration in the water. This relationship may be quantified by the "Biotic-sediment accumulator factor" (BSAF), which is the ratio between the pollutant concentration in the organism tissues and that in the surrounding sediments. This factor was successfully adopted by Song \& Breslin (1998) for the heavy metals concentrated in an amphipod (Diporeia sp.; formerly classified as Pantoporeira hoyi) from Lake Ontario. The same factor was used by Landrum \& Nalepa (1998) for the same amphipod from the same lake for evaluating its contamination by PAH (polycyclic aromatic hydrocarbons), PCB (polychlorinated byphenyls), $\mathrm{BaP}$ (benzo(a)pirene) and HCBP (hexachlorobiphenyls). Because these pollutants are accumulated in the lipids, Landrum \& Nalepa (1998) calculated the BSAF on the ratio between the pollutant concentration in the lipid content of the organism and that referring to the organic carbon content in the sediment (De Toro et al. 1991).

Landrum \& Nalepa (1998) used the "Bioaccumulation factor" (BAF), that is, the value of the pollutant concentration in the organism (wet weight) and that in the sediment (dry weight) or the pollutant concentration in the small sediment particles (dry weight), supposed to be a food source to the organism studied (Diporeia).

Song and Breslin (1998) established for Diporeia from Western Lake Ontario a relationship between the sediment metal enrichment factor (E.F.) and the BSAF factor. The E.F. factor is the ratio between the ratio of the metal (M) to the amount of aluminium in the sedi- ment and that of the same metal to the amount of aluminium in the continental crust (Wedepohl 1995):

$$
\text { E.F. }=(\mathrm{M} / \mathrm{Al}) \text { sediment/(M/Al)crust }
$$

The E.F. values showed that $\mathrm{Fe}, \mathrm{Cr}$ and $\mathrm{V}$ concentrations in the sediments were natural, because their values varied about the unit, while those of the other metals were more or less influenced by anthropogenic pollution. Indeed, the E.F. values for $\mathrm{Cu}, \mathrm{Zn}$ and $\mathrm{Ni}$ varied from 2 to 6 and those calculated for $\mathrm{As}$ and $\mathrm{Cd}$ were respectively 16 and 39 .

The "Biota-sediment accumulator factor" (BSAF) was also adopted by De Jonge et al. (1999) to quantify the accumulation of trace metals and organic pollutants by oligochaetes (Tubifex sp.) exposed to contaminated sediments. The BSAF of trace metals was calculated on the concentrations in the dry weight of the oligochaetes and the sediments, while the BSAF of organic pollutants was based on the concentration in the lipids of the oligochaetes and the pollutant concentration in the sediment referred to their content of organic carbon.

\section{DISCUSSION AND CONCLUSIONS}

The commonly used methods of biological monitoring highlight abnormalities in: community structure (e.g. diversity measurements), presence or absence of certain taxa (e.g. biotic indices, saprobic scale) or genetic, morphological, physiological or biochemical characteristics at individual or population levels.

The biological responses obtained with these techniques are related to the global situation of the environment and not to a well defined stress. The biological reaction may be the combined result of both natural causes and pollution, or of natural fluctuations of certain populations belonging to the community. In addition, the acclimation capacity, the selection of resistant strains, the geographical distribution of the species and the interrelationships between the species (e.g. predation, competition) may modify the theoretical picture of the relationships between pollution level and the presence or absence of certain indicator species.

Although the alteration of the biota is often attributed to anthropogenic pollution, this may not be the case or may be so only partially; also the influence of the physical and chemical characteristics of the environment on both the biota and the pollutants is not always considered.

Nevertheless, the various methods of biomonitoring are useful because they produce preliminary information on the wellbeing of a community and the general situation of the environment. The response of the monitoring techniques referred to above always concerns the lethal and sublethal effects. Conversely, the response to the monitoring by the accumulator species is given by the pollutant concentration in the organism. As a consequence, no biological effect can be observed because, obviously, a pollutant can be accumulated only in or- 
ganisms resistant to the pollutants. This type of monitoring cannot therefore replace the biomonitoring methods based on biological effects (e.g. biotic and diversity indices, saprobic scale), but it produces information which cannot be obtained by other methods.

The most important advantages of monitoring by accumulator organisms are the following.

a) The pollutant in the organism is identified and quantified. The information produced on the relationship between the pollutant concentration in the water and its biological effects is very rich, whereas knowledge of the relationship between the pollutant concentration in the aquatic organism and its consequences studied in the natural environment is rather scarce. By using bioaccumulators it is possible to know at what concentration of pollutant in the organism the sublethal effects begin to be evident, and particularly the effects on the reproductive mechanisms, which are so important for the survivorship probabilities of the population. This is also important because the results concern species living in their environment and not kept in laboratory conditions.

b) The various organs and tissues are analysed and consequently the "critical organs and tissues" may be identified.

c) Because of the great concentration capacity of the accumulator organisms, the pollutants may be easily measured, even when they are so diluted in the water that they cannot be analysed by the commonly used methods (e.g. Goldberg \& Martin 1983). This permits the early detection of the presence of pollutants in the environment; consequently, the accumulator organism is also referred to as a "pollution warning signal". For example, the radioisotope activity from the Chernobyl fall-out was sufficiently high in the plankton of Italian lakes to be measured five days earlier in the plankton than in the water for ${ }^{134} \mathrm{Cs}$ and ${ }^{137} \mathrm{Cs}$ and fifteen days earlier for ${ }^{131} \mathrm{I}$ (Ravera \& Giannoni 1995).

d) The presence of a pollutant in an organism is evidence that the pollutant present in the environment is, at least in part, in a bioavailable form.

e) From the comparison of the concentrations of the same pollutant in individuals of the same species collected from various environments, the relative level of contamination of each environment may be evaluated. This is based on the assumption that the concentration factor does not vary significantly between sites subject to different environmental conditions.

f) From the analysis of organisms of the same species distributed in an area it is possible to obtain the spatial distribution of the pollutants in the environment. For this purpose the species must be sedentary or fixed to a substrate (e.g. benthic animal, macrophytes). g) The variations over time of the pollution level of an environment may be monitored by the analysis of accumulator organisms. By using species with a short life-span, information on the short term variations of the pollutant level may be acquired, while to get information on long term variations, species with a long life-span must be used.

h) If the accumulator species are used as food, knowledge of their contamination level may be very useful for the human diet.

i) If the same pollutant is analysed simultaneously both in the organism and in the water (or the sediment) in which it lives, the concentration factor, or other indices (e.g. biotic-sediment accumulator factor) may be calculated and their variations over time followed.

The most suitable species to be used for this type of monitoring must have the following properties:

a) the ability to accumulate one (or more) group of pollutants in the whole body or in some critical tissues or organs;

b) presence in all seasons with an adequate biomass to allow the collection of sufficient material for chemical analyses without causing population decline;

c) if possible, wide geographical distribution, to compare the results obtained on populations of the same species from different areas;

d) organisms which are fixed, sedentary or wandering in a limited area are preferable to migratory species;

e) species with either a short or long life-span may be used, because the former are useful for detecting short term pollution and the latter for detecting long term.

Some care must be taken to obtain samples in line with the aim of the monitoring:

a) the size of the sample must be that required by the analytical methods adopted, or greater, and the number of individuals in the sample must be statistically adequate, in relation to individual variability;

b) to decrease the variability of a sample composed of several species of small sized individuals (e.g. plankton, meiobenthos), the sample may be divided into several sub-samples of successive size classes;

c) because some species (e.g. bivalves) vary their capacity for accumulating pollutants with age, to reduce the variability of the sample, the difference in size (corresponding to age) between the individuals in the sample must be quite small;

d) environmental monitoring is more complete if individuals of the same species are collected from different biotopes; for example, benthic animals from different depths, and/or from zones with slow and rapid currents.

In addition, because monitoring by "accumulator organisms" requires a well equipped chemical laboratory, a connection with chemical monitoring is to be recom- 
mended. The advantages are evident; costs are reduced, and the sampling plan and analytical methods may be better harmonised. In addition, the relationship between the pollutant concentrations in the organisms and those in their physical environment may be more easily established.

\section{REFERENCES}

Abo-Rady, M.T.K. 1980. Makrophytische Wasserpflanzen als Bioindikatoren für die Schwermetallbelastung der oberen Leine. Arch. Hydrobiol., 89: 387-404.

Absil, M.C.P., J.J. Kroon \& H.T. Wolterbeek. 1994a. Availability of copper from phytoplankton and water for the bivalve Macoma balthica. I. Separation of uptake pathreays using the radiotracer Cu-64. Mar. Biol., 118: 123-127.

Absil, M.C.P., J.J. Kroon \& H.T. Wolterbeek. 1994b. Availability of copper from phytoplankton and water for the bivalve Macoma balthica. II. Uptake and elimination from $\mathrm{Cu}-64$ labelled diatoms and water. Mar. Biol., 118: 129135.

Adams, S.M. \& C.D. Shorey. 1998. Energy dispersive spectroscopy of granular concretions in the mantle of the freshwater mussel Hyridella depressa from Lake Burragorang as a technique to monitor metals in aquatic systems. Aquatic Toxicol., 44: 93-102.

Albergoni, V. \& E. Piccinni. 1979. Regolazione e tolleranza per i metalli in Euglena gracilis. Lincei Rend. Sc. Fis. mat. e nat., 66: 209-213.

Albergoni, V. \& E. Piccinni. 1983. Biological response to trace metals and their biochemical effects. In: G.G. Leppard (Ed.). Trace element speciation in surface waters and its ecological implications. Plenum Press, New York: 159175.

Armstrong, F.A.J. \& A.L. Hamilton. 1973. Pathways of mercury in a polluted northwestern Ontario lake. In: P.C. Singer (Ed.), Trace metals and metal-organic interactions in natural waters. Ann Arbor Science Publishers: 131156.

Axelman, J., K. Naes, C. Näf \& D. Broman. 1999. Accumulation of polycyclic aromatic hydrocarbons in semipermeable membrane devices and caged mussels (Mytilus edulis, L.) in relation to water column phase distribution. Environ. Toxicol. Chem., 18: 2454-2461.

Bascombe, A.D., J.B. Ellis, D.M. Revitt \& R.B.E. Shutes. 1990. The development of ecotoxicological criteria, in urban catchments. Water Sci. Technol., 23: 173-179.

Bishop, J.N. \& B.P. Neary. 1974. The form of mercury in freshwater fish. Laboratory Services Branch, Ontario Ministry of the Environment.

Borchardt, T. 1983. Influence of food quality on the kinetics of cadmium uptake and loss via food and seawater in Mytilus edulis. Mar. Biol., 76: 67-76.

Borgmann, V. \& W.P. Norwood. 1955. EDTA toxicity and background concentrations of copper and zinc in Hyabella azteca. Can. J. Fish. aquat. Sc., 52: 875-881.

Boyden, C.R. 1977. The effect of size upon metal content of shellfish. J. Mar. Biol. Assoc. U.K., 57: 675-714.

Bradley, H.C. 1970a. The occurrence of manganese in freshwater clam. Science, 25: 456.

Bradley, H.C. 1970b. Manganese. A normal element in tissues of freshwater clams: Unio and Anodonta. J. Biol. Chem., 3: 151 .

Brown, B.E. 1982. The form and function of metal-containing "granules" in invertebrates tissues. Biol. Rev., 57: 621-667.

Bruner, K.A., S.W. Fisher \& P.F. Landrum. 1994. The role of the zebra mussel, Dreissena polymorpha in contaminant cycling. 1 . The effect of body size and lipid content on the bioconcentration of PCBs and PAHs. J. Great Lakes Res., 20: $725-734$.
Cenci, R.M. 1993. Il muschio Fontinalis antipyretica utilizzato quale bioindicatore di inquinamento nelle acque da mercurio e piombo. Studi Sassaresi, Ann. Fac. Agraria, Univ. di Sassari, 35: 469-478.

Chen, R.W., P.D. Whanger \& P.H. Weswig. 1975. Biological function of metallothionein. I Synthesis and degradation of rat liver metallothionein. Biochem. Med., 12: 95.

Connel, D.B. \& J.G. Sanders. 1999. Variation in cadmium uptake by estuarine phytoplankton and transfer to the copepod Eurytemora affinis. Marine Biology, 133: 259-265.

Czarnezki, J.M. 1987. Use of the pocketbook mussel, Lampsilis ventricosa for monitoring heavy metal pollution in an Ozark stream. Bull. Environ. Contam. Toxicol., 38: 641646.

De Bortoli, M., P. Gaglione, A. Malvicini \& C. Polvani. 1968. Concentration factors for strontium and caesium in fish of the lakes in the region of Varese (Northern Italy). Giorn. Fish. San. Radioprot., 12: 324-331.

De Jonge, J., J.M. Brils, A.J. Hendriks \& W.C. Ma. 1999. Ecological and ecotoxicological surveys of mederately contaminated floodplan ecosystems in The Netherlands. Aquatic Ecosys. Health Manage., 2: 9-18.

De Toro, D.M., C.S. Zarba, D.J. Hansen, W.J. Berry, R.C. Swartz, C.E. Cown, S.P. Pavlou, H.S. Allen, N.A. Thomas \& P.R. Paquin. 1991. Technical basis for establishing sediment quality criteria for non-ionic organic chemicals by using equilibrium partitioning. Environ. Toxicol. Chem., 10: 1541-1583.

Doherty, F.G., D.W. Evans \& E.F. Neuhauser. 1993. An assessment of total and leachable contaminants in zebra mussels (Dreissena polymorpha) from Lake Erie. Ecotoxicol. Environ. Saf., 25: 328-340.

Ellis, G.S., J.N. Huckins, C.E. Rostand, C.J. Schmitt, J.D. Petty \& P. Mac Carthy. 1995. Evaluation of lipid containing semipermeable membrane devices for monitoring organochlorine contaminants in the upper Mississippi River. Environ. Toxicol. Chem., 14: 1875-1884.

Ferrington, J.W., E.D. Goldberg, R.W. Risebrough, J.H. Martin \& V.T. Bowen. 1983. U.S. Mussel Watch 1976-1978: An overview of the trace-metal, DDT, PCB, hydrocarbon and artificial radionuclide data. Environ. Sci. Technol., 17: 490-496.

Flanagan, P.J. \& P.F. Toner. 1972. Notes on the chemical and biological analysis in Irish river waters. An Foras Forbartha, Water Resources Division. St. Martin's House, Dublin.

Gaglione, P. \& O. Ravera. 1964. Manganese-54 concentration in fall-out, water and Unio mussels of Lake Maggiore, 1960. Nature, 204: 1215-1217.

Goldberg, E.D. \& J.H. Martin. 1983. Metals in seawater as recorded by mussels. In: C.S. Wong, E. Boyle, K.W. Bruland, J.D. Burton \& E.D. Golberg (Eds), Trace metals in sea water. Plenum Press, New York: 811-823.

Gommes, R. \& H. Muntau. 1976. Cadmium levels in biota and abiota from Lake Maggiore. EUR 5411.

Hannerz, L. 1966. Fall-out Cs-137 in fish and plankton from Lake Mälar and the Baltic. Acta Radiol., 254 (Suppl.): 2228.

Harvey, R.W. \& S.N. Luoma. 1985. Separation of solute and particulate vectors of heavy metal uptake in controlled suspension-feeding experiments with Macoma balthica. Hydrobiologia, 121: 97-102.

Havre, G.N., B. Underdal \& C. Christiansen. 1972. The content of lead and some other heavy elements in different fish species from a fjord in Western Norway. Intern. Symposium Environmental health aspects of lead. CEC-EPA, Amsterdam, 2-6 October: 99-111.

High, K.A., V.J. Barthet, J.W. Mc Laren \& J.S. Blais. 1997. Characterisation of metallothionein-like proteins from zebra mussels (Dreissena polymorpha). Environ. Toxicol. Chem., 16: 1111-1118. 
Hofelt, C.S. \& D. Shea. 1997. Accumulation of organochlorine pesticide and PCBs by semipermeable membrane device and Mytilus edulis in New Bedford Harbor. Environ. Sci. Technol., 31: 154-159.

Hopkin, S.P. \& J.A. Nott. 1979. Some observations on concentrically structured, intracellular granules in the hepatopancreas of the shore crab Carcinus maenas (L.). J. Mar. Biol. Assoc. U.K., 59: 867-877.

Huckins, J.N., M.W. Tubergen \& G.K. Manuweera. 1990. Semipermeable membrane devices containing model lipid. A new approach to monitoring the bioavailability of lipophilic contaminants and estimating their bioconcentration potential. Chemosphere, 20: 533-552.

Iorgulescu, A., M. Oncescu, O. Serbanescu \& F. Porumb. 1965. Active fission gamma elements identified in marine plankton. Rev. Rom. Biol., 10: 373-378.

Janssen, H.H. \& N. Scholz. 1979. Uptake and cellular distribution of cadmium in Mytilus edulis. Mar. Biol., 55: 133141

Jernelov, A. 1972. Mercury and food chains. In: R. Hartung \& J. Dinan (Eds), Environmental Mercury Contamination. Ann Arbor Sc. Publishing, Ann Arbor: 174-177.

Kim, S.D., H. Ma, H.E. Allen \& D.K. Cha. 1999. Influence of dissolved organic matter on the toxicity of copper to Ceriodaphnia dubia: effect of complezation kinetics. Env. Toxicol. Chem., 18: 2433-2437.

Landrum, P.F. \& T.F. Nalepa. 1998. A review of the factors affecting the ecotoxicology of Diporeia spp. J. Great Lake Res., 24: 889-904.

Larsson, P., L. Collvin, L. Okla \& G. Meyer. 1992. Lake productivity and water chemistry as governor of the uptake of persistent pollutants in fish. Environ. Sci. Technol., 26: 346-352.

Latufo, G.R. 1998. Bioaccumulation of sediment - associated fluoranthene in benthic copepods: uptake, elimination and biotransformation. Aquatic Toxicol., 44: 1-15.

Lindberg, S., P.M. Stokes, E. Goldberg \& C. Wren. 1987. Group report: Mercury. In: T.C. Hutchinson \& K.M. Meema (Eds), Lead, Cadmium, Mercury and Arsenic in the Environment. John Wiley \& Sons, New York: 17-33.

Lobel, P.B. \& D.A. Wright. 1982. Gonadal and non-gonadal zinc concentrations in mussels. Marine Poll. Bull., 13: 320-323.

Lowman, F.G. 1958. Radionuclides in plankton near the Marshall Islands, 1956. AEC - Document UWFL, 54.

Lucas, H.F. \& D.N. Edgington \& P.J. Colby. 1970. Concentrations of trace elements in Great Lake fish. J. Fish. Res. Bd Can., 27: 677-684.

Munger, C., L. Hare, A. Craig \& P.M. Charest. 1999. Influence of exposure time on the distribution of cadmium with the Cladocerans Ceriodaphnia dubia. Aquatic Toxicol., 33: $195-200$

Naimo, T.J. 1995. A review of the effects of heavy metals in freshwater mussels. Ecotoxicology, 4: 341-362.

Neal, E.E., B.C. Patten \& C.E. Poe. 1967. Periphyton growth on artificial substrates in a radioactively contaminated lake. Ecology, 48: 918-924.

Nott, J.A. \& A. Nicolaidu. 1994. Variable transfer of detoxified metals from snails to hermit crabs in marine food chains. Mar. Biol., 120: 369-377.

O'Connor, T.P., A.Y. Cantillo \& G.G. Lauenstein. 1994 Monitoring of temporal trends in chemical contamination by the NOAA National Status and trends Mussel Watch Project. In: K.J.M. Kramer (Ed.). Biomonitoring of Coastal Waters and Estuaries. CRC Press, Boca Raton, Fl.

Oertel, N. 1991. Heavy-metal accumulation in Cladophora glomerata (L.) Kütz, in the River Danube. Ambio, 20: 264-268.

Oertel, N. 1993. The applicability of Cladophora glomerata (L.) Kütz in an active biomonitoring technique to monitor heavy metals in the river Danube. The Science of the Total Environment (Suppl.): 1293-1304.

Oertel, N. 1998. Molluscs as bioindicators of heavy metals in a side-arm system of the River Danube disturbed by engineering activities. Verh. Internat. Verein. Limnol., 26: 2120-2124.

Parks, J.W., J.A. Sutton \& J.D. Hollinger. 1984. Mercury Pollution in the Wabigoon - English River System of Northwestern Ontario, and Possible Remedial Measures Technical Report. Government of Canada and Government of Ontario: $538 \mathrm{pp}$

Perret, P. 1977. Zustand der Schweizerischen Fliesswässer in den Jahren 1974-1975 (Project MAPOS). EAWAG Dubendorf.

Phillips, G.R. \& D.R. Buhler. 1978. The relative contributions of methylmercury from food or water to rainbow trout (Salmo gairdneri) in a controlled laboratory controlled environment. Trans. am. Fish. Soc., 107: 853-861.

Plénet, S. 1995. Freshwater amphipods as bioindicators of metal pollution in surface and interstitial aquatic systems. Freshawat. Biol., 33: 127-137.

Premazzi, G., R. Bertone, A. Freddi \& O. Ravera. 1979. Combined effects of heavy metals and chetating substances on Selenastrum cultures. In: Proc. Seminar on Ecological tests relevant to the implemention of proposed regulations concerning environmental chemicals: evaluation and research needs. Berlin, Dec. 7-9, 1977: 169-187.

Rainbow, P.S., P.G. More \& D. Watson. 1989. Talitrid amphipods as biomonitoring for copper and zinc. Estuarine, Coastal Shelf Sci., 28: 567-582.

Ravera, O. 1964. The radioactivity of Viviparus ater Crist. and Jan, freshwater Mollusc, in relation to that of sediment. Bull. FEPE, 10: 61-65.

Ravera, O. 1965. Radioactivity in freshwater organisms in some lakes of Northern Italy. Proc. $3^{\text {rd }}$ Seminar Biological Problem in Water Pollution. U.S. Dep. Education Welfare, Cincinnati: 195-201

Ravera, O. 1966. L'utilità delle piante acquatiche nello studio delle contaminazioni radioattive dei bacini lacustri. Giorn. Fisica San. Radioprot., 10: 162-165.

Ravera, O. 1971. Sr-85 and Cs-134 uptake by freshwater seston. Rev. Intern. Oceanogr. Méd., 21: 109-124.

Ravera, O. 1998. Utility and limits of biological and chemical monitoring of the aquatic environment. Annali Chimica, 88: 909-913.

Ravera, O. \& L. Vido. 1961. Misura del Mn-54 in popolazioni di Unio pictorum, L. (Molluschi, Lamellibranchi) del Lago Maggiore. Mem. Ist. ital. Idrobiol., 13: 75-84.

Ravera, O. \& M. Mazzoleni. 1965. Contenuto e ricambio del fosforo in una popolazione di Viviparus, Crist. e Jan (Gasteropode, Prosobanco). Boll. Zool., 32: 875-884.

Ravera, O. \& L. Giannoni. 1995. Plankton as an indicator of variation over time of the Chernobyl fall-out. The Science of the Total Environment, 172: 119-125.

Ravera, O., A. Cartisano, R. de Bernardi \& L. Guzzi. 1973. Effects of chelating agents (EDTA and SNTA) on the incorporation of radionuclides by freshwater filter feeding organisms (Copepoda and Lamellibranch). Atti $5^{\circ}$ Coll. Intern. Oceanogr. Med., Messina: 437-448.

Recht, P. 1969. Principi e metodologia generale per la determinazione della capacità radiologica limite di una rete idrobiologica. C.E.C. Direzione Generale Affari Sociali e Direzione Protezione Sanitaria, Bruxelles.

Reichenbach-Klinke, H. 1971. Der Fish als Indicators der Umwelt. Z. Wasser-Abwasser-Forschung, 4: 12-15.

Rice, C.P. \& H.C. Sikka. 1973. Fate of dieldrin in selected species of marine algae. Bull. Environ Contam. Toxicol., 9: 116-121.

Richman, L.A., C.D. Wrenn \& R.M. Stokes. 1988. Facts and fallacies concerning mercury uptake by fish in acid stressed lakes. Water Air Soil Pollut., 37: 465-473. 
Rose, J., M.S. Hutcheson, C.R. West, O. Pancorbo, K. Hulme, A. Cooperman, G. De Cesare, R. Isaac \& A. Screpetis. 1999. Fish mercury distribution in Massachusetts, U.S.A. lakes. Env. Toxicol. Chem., 18: 1370-1379.

Schreiber, B. 1967. Ecology of Acantharia in relation of $\mathrm{Sr}$ circulation in the sea. Final rep. IAEA. Contract US/62.1967.

Song, K.H. \& V.T. Breslin. 1998. Accumulation of contaminant metals in the amphipod Diporeia spp. in western Lake Ontario. J. Great Lakes Res., 24: 949-961.

Sprague, J.B. 1968. Promising unpollutant: chelating agent NTA protect fish from copper and zinc. Nature, 220: $1345-1346$.

Sures, B., W. Steiner, M. Rydlo \& H. Taraschwski. 1999. Concentrations of 17 elements in the zebra mussel (Dreissena polymorpha), in different tissues of perch (Perca fluviatilis) and in perch intestinal parasites (Acanthocephalus lucii) from the subalpine Lake Mondsee, Austria. Environ. Toxicol. Chem., 18: 2574-2579.

Tassi-Pelati, L. 1969. Importanza dei molluschi nel ciclo biogeochimico dello stronzio. Contenuto di Sr-90 e di Ra-226 nel guscio di Tellina pusilla. Rend. Sc. Ist. Lombardo Sc. Lett., 103: 84-92.

Templeton, W.L. 1959. Fission products and aquatic organisms. In: The effect of pollution on living material. Institute of Biology (Sept. 1958). London, 8: 125-140.
Twiss, M.R. \& P.G.C. Campbell. 1998. Scavenging of ${ }^{137}$ Cs, ${ }^{109} \mathrm{Cd},{ }^{65} \mathrm{Zn}$ and ${ }^{153} \mathrm{Gd}$ by plankton of the microbial food web in pelagic Lake Erie surface waters. J. Great Lakes Res., 24: 776-790.

Vymazal, J. 1984. Shott term uptake of heavy metal by periphyton algae. Hydrobiologia, 119: 171-179.

Wedepohl, K.H. 1995. The composition of the continental crust. Geochim et Cosmochim Acta, 59: 1217-1232.

Whitton, B.A., I.G. Burrows \& M.G. Kelly. 1989. Use of Cladophora glomerata to monitor heavy metals in the rivers. J. Appl. Phycol., 1: 293-299.

Willman, E.J., J.B. Manchester-Neesvig, C. Agrell \& D.E. Armstrong. 1999. Influence of ortho-substitution homolog group on polychlorobiphenyl bioaccumulation factors and fugacity ratios in plankton and zebra mussels (Dreissena polymorpha). Environ. Toxicol. Chem., 18: 1380-1389.

Zamuda, C.D. \& W.G. Sunda. 1982. Bioavailability of dissolved copper to the American oyster Crassostrea virginica. I. Importance of chemical speciation. Mar. Biol., 66: 77-82.

Zatta, P. 1985. Interaction between $\mathrm{Zn}^{++}, \mathrm{Co}^{++}, \mathrm{Mn}^{++}$with hemocyanin from Carcinus maenas. Cahier de Biol. Marine, 26: 241-249. 